\title{
Design, Construction, and Simulation of a Solar Fish Dryer
}

\author{
Sule Salisu1, Oyejide Oluwayomi Joel ${ }^{2}$, Akusu Onomine Murray1
}

\author{
${ }^{1}$ Department of Mechanical Engineering, Petroleum Training Institute, Effurun, Nigeria \\ ${ }^{2}$ Department of Mechanical Engineering, Federal University of Petroleum Resources, Effurun, Nigeria
}

\begin{abstract}
The use of solar thermal systems in the agricultural sector to conserve vegetables, fruits, coffee, fish and other crops has proved to be practical, and economical feasible. Solar heating system to dry fish, food and other crops can improve the quality of the product, reducing wastage of food as a result of lack of proper preservation. Fish is traditional dry in Nigeria via smoking which is unhygienic. The traditional method of using wood fuel has negative impact on our eco-system. In this research work, design, construction and optimization of a solar fish dryer were carried out. The temperature of the inner surface of the glass (dryer) was determined as $94.8^{\circ} \mathrm{C}$. The result obtained from the design of the drying chamber shown that an area of $0.12 \mathrm{~m} 2$ is required for the system. Moreover, the area of the flat plate collector was obtained as $0.49 \mathrm{~m} 2$. The temperature of the sun acting on the outer surface of the plane glass was obtained as $268.4^{\circ} \mathrm{C}$ while the effective heat gain is obtained as $0.115 \mathrm{kw}$.
\end{abstract}

\section{KEYWORDS: Design, SolidWorks simulation, Fish, Solar dryer, Temperature, Heat gain}

\section{INTRODUCTION}

Fish is an essential component of human diet accounting for $65 \%$ of protein intake [1]. Due to increase in consumption of fish by average Nigerians, the demand for it is on the rise [2]. It is estimated that Nigeria imports about 29,000tons of dry fish annually [3], amounting to a significant outflow of foreign currency from the country. One major problem with the Nigeria fish industry is the preservation of harvested fish [4]. Improving the local dry fish industry can help to preserve fish especially during the rainy season where much harvest is recorded [5]. Dry fish production mainly consists of micro level cottage enterprises, carried out predominantly by petty traders, fishermen and fisherwomen as a supplementary source of income. As such the quantity produced tends to be low. Furthermore, due to the long drawn drying process moisture retained creates an ideal environment for growth [6]. The practice of drying fish in the open in the sun affects the hygienic conditions of the fish, due to the high risk of contamination with dust particles' and harmful bacteria [7].

However, the scale of the average dry fish enterprises precludes the introduction of sophisticated methods of fish preservation [8]. The high capital requirements and the fuel cost of many of the high-tech driers make it unaffordable and impracticable for the small scale dry fish producers in Nigeria [9]. Moreover, social factors such as; attitudes, lifestyles and behaviour makes it difficult to introduce radical changes to conventional drying methods [10]. A distinct departure must be made from the age-old techniques of exclusively using manual aid animal labour, animal wastes and firewood or charcoal as the main source of energy [11]. Past experiences has shown that such methods are highly regressive to human and environmental conditions [12]. Thus, the use of renewable energy sources like solar energy in its various forms should therefore be encouraged in developing countries especially for agricultural product in Nigeria.

Solar energy is seen as a pedestal for various forms of renewable energy [13]. It supports hydro power in which the hydrological cycle is controlled by the sun and wind power where the movement of air is cause by the heating effect of the sun on the environment. Generally, energy in form of; heat, kinetic energy, electrical energy and chemical energy are provided via solar energy conversion [14]. Nigeria lies between latitudes 40 and $140 \mathrm{~N}$, and longitude 20 and $150 \mathrm{E}$ of the equator, hence Nigeria is located in a tropical hot climate. Nigeria receives an average of about $3.5 \mathrm{kwh} / \mathrm{m}^{2} /$ day $\left(12.6 \mathrm{MJ} / \mathrm{m}^{2} /\right.$ day) in the coastal latitudes and about $7.0 \mathrm{kwh} / \mathrm{m}^{2} /$ day $\left(25.2 \mathrm{MJ} / \mathrm{m}^{2} /\right.$ day $)$ in far north of the country of incident solar energy [15]. In view of this abundant sunshine all year round, the location of the country within the humid tropical region and the characteristic isolated pattern of human settlement, Solar Photovoltaic (PV) technology are particularly well suited for use in Nigeria [13]. Thus, there is the need to tap into the Nigeria solar energy sector. This research work is focused on the design, construction, and optimization of a solar fish dryer.

\section{Materials and Methods}

The major components of the machine are: the flat plate solar collector, absorber plate, glass (transparent cover), dry chamber, wire gauze, insulator, carriage (roller).

\subsection{The Flat Plate Solar Collector}

The flat plate collector consists of; a transparent cover (glass), an absorber (oven baked aluminium), the insulation, and the container of collector body. Flat plate collector was fixed in a south-facing position (in the northern hemisphere) and tilled upward from the horizontal at an angle $\left(\varnothing=15^{\circ}\right)$ which is suitable for our design. The function of the solar collector is to transform the short wave radiant energy from the sun into thermal/heat energy.

\subsection{Transparent Cover (Glass)}

The function of the glass cover in the collector is to create greenhouse effect. Glass is highly transparent to the sun's short wave radiation but completely opaque to the long wave radiation emitted by the heated collector plate and retard convective heat transfer from the plate. It is also unaffected by the sun's ultraviolet radiation, which is highly destructive to most plastic films. 


\subsection{Absorber Plate}

The absorber plate is oven baked aluminium blackened to convert the incoming short wave radiation to heat. It absorbs both direct and diffused radiation. The surface should have high absorption for solar radiation and low emitted for long wave radiation.

\subsection{The Insulator (Colatex Material)}

It is used to insulate the interior parts of the solar collector so as to reduce heat loss from the absorber. Also the drying chamber is insulated to reduce excessive heat loss. Colatex is used as the insulator in this design because it is a good heat insulator and readily available at low cost.

\subsection{Collector Body Cover (Wood)}

The entire unit of the solar collector is designed such that the side body covers extends to the dryer unit. The collector body cover is made of wood material. It is readily available and a good insulator.

\subsection{Drying Chamber}

This is the place or space where dehydration of the fish occurs. The objective of dehydration is of course, to reduce the water content of the fish to a point where it can no longer support the growth of micro-organisms. Of these organisms, bacteria and yeasts cease to multiply in the fish when the water content is less than $25 \%$ of the total body weight and moulds when it is less than $15 \%$. The design of the drying chamber was done to permit the user to use it as in-bin storage dryer.

\subsection{Wire Gauze}

This is where the fishes to be dried are spread. The products being dried are put on the wire gauze so that heated air from the collector can easily pass through the gauze and consequently cause drying. The wire gauze is of mild steel material and has high resistance to corrosion.

\subsection{Carriage}

A means of easy movement is attached to the system as a unit. A roller type tyre is fixed to the collector while a supporting frame is attached to it.

\subsection{Solar Collector Temperature}

The rate of energy radiation from the sun is given as;

$$
\dot{\mathrm{E}}_{\text {gun }}=\xi_{s} \times \sigma \times T_{3}^{4}[16]
$$

Where;

$\dot{\mathrm{E}}_{\text {gun }}=$ Rate of energy radiation from the Sun

$\xi_{s}=$ Emissivity of the Sun

$\sigma=$ Stefan Boltzman constant $=5.67 \times 10^{-8} \mathrm{w} / \mathrm{m}^{2} \mathrm{k}^{4}$

$T_{s}^{4}=$ Temperature of radiant energy from the Sun

But for the Sun, emissivity $\left(\xi_{\varepsilon}\right)$ ranges from zero $(0)$ to unity

(1) or equal to 1 [17]

$\mathrm{E}_{\text {gun }}=5.67 \times 10^{-8} \mathrm{~T}^{4}$

\subsection{The rate of radiant energy to be absorbed by the plane glass is;$$
\dot{\mathrm{E}}_{\text {glass }}=\alpha_{g} \times \sigma \times \mathrm{T}_{g}^{4}[20]
$$

Where;

$\alpha_{\mathrm{g}}=$ Absorptivity of plane glass given as 0.06 [17]

$T_{g}^{4}=$ Ambient temperature of glass $32^{\circ} \mathrm{C}=305 \mathrm{k}$

Equating equation (1) and equation (2)

$\dot{\mathrm{F}}_{\text {sun }}=\mathrm{E}_{\text {glass }}$

$5.67 \times 10^{-8} T_{3}^{4}=0.06 \times 5.67 \times 10^{-8} \times 305^{4}, T_{3}^{4}=5,192,190,375$

$T_{3}=\sqrt[4]{5,192,190,375}, T_{3}=268.4^{\circ} \mathrm{C}$

Thus, temperature of the sun acting on the outer surface of the plane glass is $268.4^{\circ} \mathrm{C}$

But,

$$
\mathrm{Q}_{\mathrm{c}}=K_{g} A_{g}\left(\mathrm{~T}_{\circ}-\mathrm{T}_{\text {in }}\right)
$$

Where;

$\mathrm{K}_{\mathrm{g}}=$ Thermal conductivity of plane glass given as $1.4 \mathrm{w} / \mathrm{m}^{2}{ }^{\circ} \mathrm{C}$ [17]

$\mathrm{A}_{\mathrm{g}}=$ Surface area on plane glass in $\mathrm{m}^{2}$

$\mathrm{T}_{\mathrm{o}}=$ Temperature of the sun is measured in ${ }^{\circ} \mathrm{C}$.

$\mathrm{T}_{\mathrm{in}}=$ Temperature of collector inner surface

$$
\mathrm{Q}_{c}=h_{a} A_{c}\left(T_{i n}-T_{d}\right)
$$

Where;

$\mathrm{h}_{\mathrm{a}}=$ Convective heat transfer coefficient of air $\left(40 \mathrm{w} / \mathrm{m}^{2 \circ} \mathrm{C}\right)$

$\mathrm{A}_{\mathrm{c}}=$ Area of drying chamber

$\mathrm{T}_{\mathrm{d}}=$ Design Temperature $70^{\circ} \mathrm{C}$

Equating equation (3) and equation (4)

$$
K_{g} A_{g}\left(T_{o}-T_{\text {in }}\right)=h_{\mathrm{x}} A_{c}\left(T_{\text {in }}-T_{d}\right)
$$

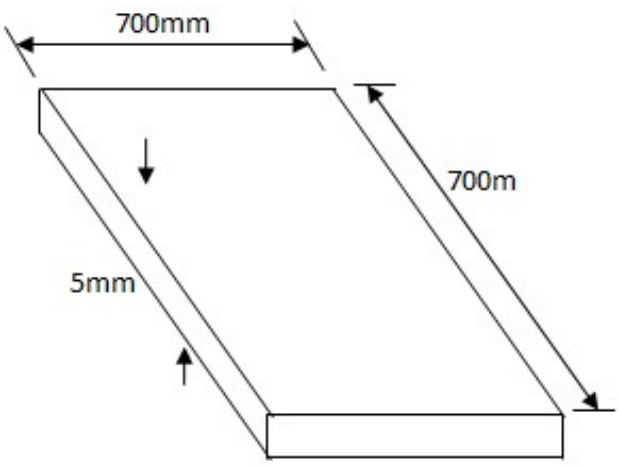

Fig.1 Flat Plate Collector

The area of the flat plate collector was calculated as;

Area $=$ Length $\times$ Breadth $=0.7 \mathrm{~m} \times 0.7 \mathrm{~m}=$

$0.49 m^{2}$ 


\subsection{Area of Drying Chamber $\left(A_{c}\right)$ or Collector Box}

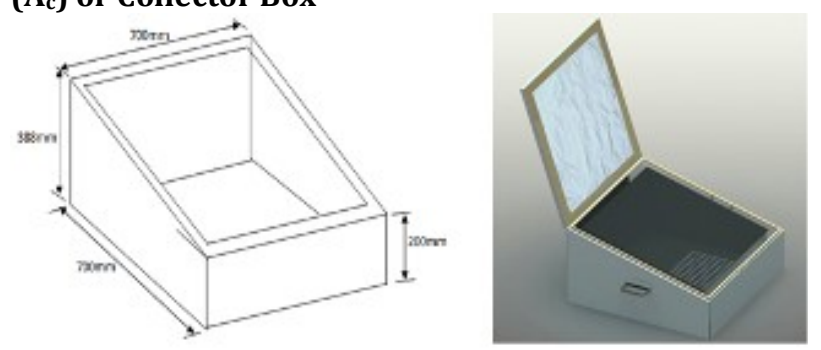

Fig. 2 Drying Chamber

The area of drying chamber is calculated from equation (6),

$A_{c}=(L \times B \times H)+\frac{1}{2} \mathrm{AB} \sin \theta$

$A_{c}=(0.7 \times 0.7 \times 0.7)+\frac{1}{2}(0.7 \times 0.188 \sin 15)=$

$0.12 m^{2}$

\subsection{Solar Collector Useful Heat Gain}

The useful heat gain by the solar collected is calculated as;

$K_{g} A_{g}\left(T_{o}-T_{i n}\right)=h_{a} \Lambda_{c}\left(T_{i n}-T_{d}\right)$

$1.4 \times 0.49\left(268.4-T_{\text {in }}\right)=40 \times 0.12\left(T_{\text {in }}-70\right)$

$T_{\text {in }}=94.8^{\circ} \mathrm{C}$

Thus, $94.8^{\circ} \mathrm{C}$ is the temperature of the inner surface of the glass (dryer)

But,

$Q_{\alpha}=K_{\theta} A_{Q}\left(T_{\theta}-T_{\text {ix }}\right)=1.4 \times 0.49(2.68 .4-9.4 .8)=119.08 \mathrm{w}$ or $0.119 \mathrm{kw}$

Thus the useful heat gain by the solar collector is $0.119 \mathrm{kw}$

\subsection{Effective Heat of Collector $\left(Q_{c}\right)$}

The effective heat gain is given by equation (7);

$\mathrm{Q}_{\mathrm{c}}=h_{\mathrm{a}} A_{c}\left(T_{\text {in }}-\mathrm{T}_{\mathrm{d}}\right)$

Where;

$\mathrm{h}_{\mathrm{a}}=$ Convective heat transfer coefficient of air $40 \mathrm{w} / \mathrm{m}^{2} \mathrm{C}$

$\mathrm{A}_{\mathrm{c}}=$ Area of drying chamber $\left(0.12 \mathrm{~m}^{2}\right)$

$\mathrm{T}_{\mathrm{d}}=$ Design Temperature of solar dryer which is $70^{\circ} \mathrm{C}$

$Q_{c}=h_{a} A_{c}\left(T_{\text {in }}-T_{d}\right) 40 \times 0.12(94.8-70)=115.04 \mathrm{w}$ or $0.115 \mathrm{kw}$

There is a reduction in the effective heat as a result of heat absorbed by the aluminium and side heat transfer.

\subsection{Simulation with Solid Work}

Solid Work is a solid modeler that make use of parametric (i.e. constraints whose values can determine the geometry of the model) features (i.e. building blocks of the part) base approach to create models [21]. The model information is shown in Figure 3.

Model Information

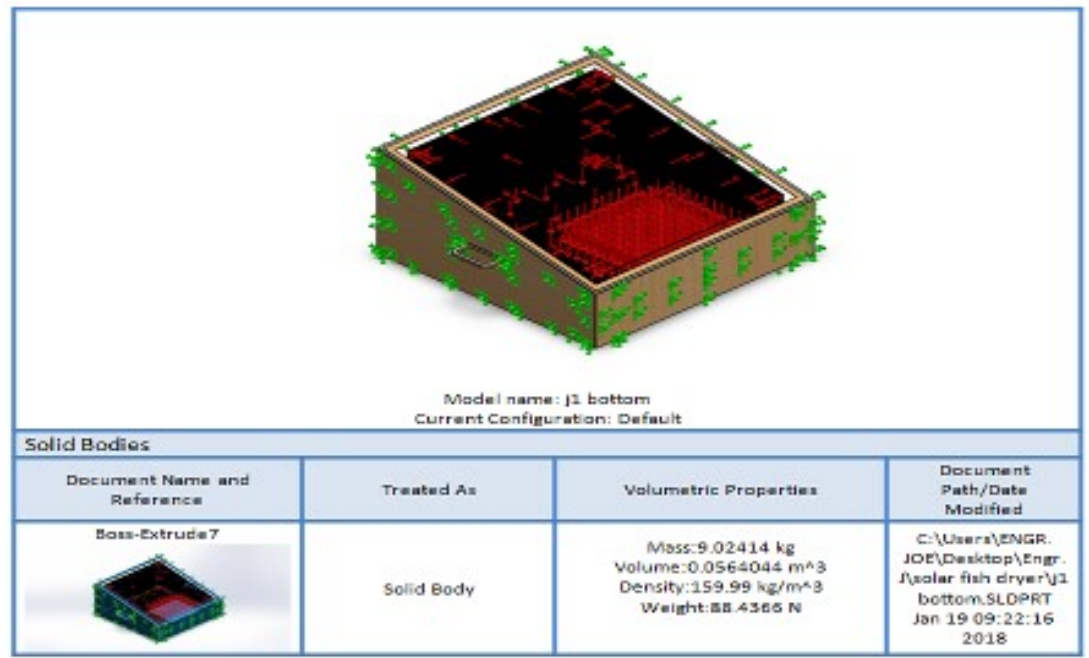

Fig. 3 Model Information 


\section{Results and Discussion}

The designed and constructed solar dryer was placed on an open environment of Petroleum Training Institute, Effurun, Nigeria. The initial weight of the fish to be dried was taken and recorded. The fish was placed on the wire gauze which was on top of a pan and then placed inside the drying chamber of the solar dryer. Finally the weight of the fish was then measured at an hour interval and their corresponding time was recorded, using a thermometer, which was placed inside the drying chamber of the solar fish dryer. The results obtained were tabulated as shown in Table 1. The performance test was carried out in the month of June, Latitude $5^{\circ} \mathrm{N}$ at Petroleum Training Institute, Effurun, Delta State.

Table 1 Performance Test Results

\begin{tabular}{|c|c|c|c|c|}
\hline S/N & $\begin{array}{l}\text { Initial Moisture } \\
\text { Content(kg) }\end{array}$ & $\begin{array}{l}\text { Final Moisture Content } \\
\text { (Kg) }\end{array}$ & $\begin{array}{l}\text { Drying Temperature } \\
\left({ }^{\circ} \mathrm{C}\right)\end{array}$ & $\begin{array}{l}\text { Time for drying } \\
\text { (hr.) }\end{array}$ \\
\hline 1 & 3 & 2.9 & 35 & 8:00am - 9:00am \\
\hline 2 & 2.9 & 2.8 & 45 & 9:00am - 10:00am \\
\hline 3 & 2.8 & 2.6 & 54 & $\begin{array}{c}\text { 10:00am - } \\
\text { 11:00am }\end{array}$ \\
\hline 4 & 2.6 & 2.4 & 68 & 11:00am - 12 noon \\
\hline 5 & 2.4 & 2.1 & 69 & 12 noon - 1:00pm \\
\hline 6 & 2.1 & 1.9 & 60 & 1:00pm - 2:00pm \\
\hline 7 & 1.9 & 1.85 & 54 & 2:00pm - 3:00pm \\
\hline 8 & 1.85 & 1.8 & 42 & 3:00pm - 4:00pm \\
\hline
\end{tabular}

The design was done to achieve maximum output. The mode of operation of the combined dryer system is discussed with a view to establishing how best the design calculations meet with practical results obtained. Figure 4 shows the graph of temperature against time. It was discovered that there is a considerable increase in temperature in the early hour of the day, but around 2pm the temperature was observed to drop as a results of change in weather condition. The highest temperature was obtained in the afternoon $(1 \mathrm{pm})$ while the lowest was in the morning ( $9 \mathrm{am})$.

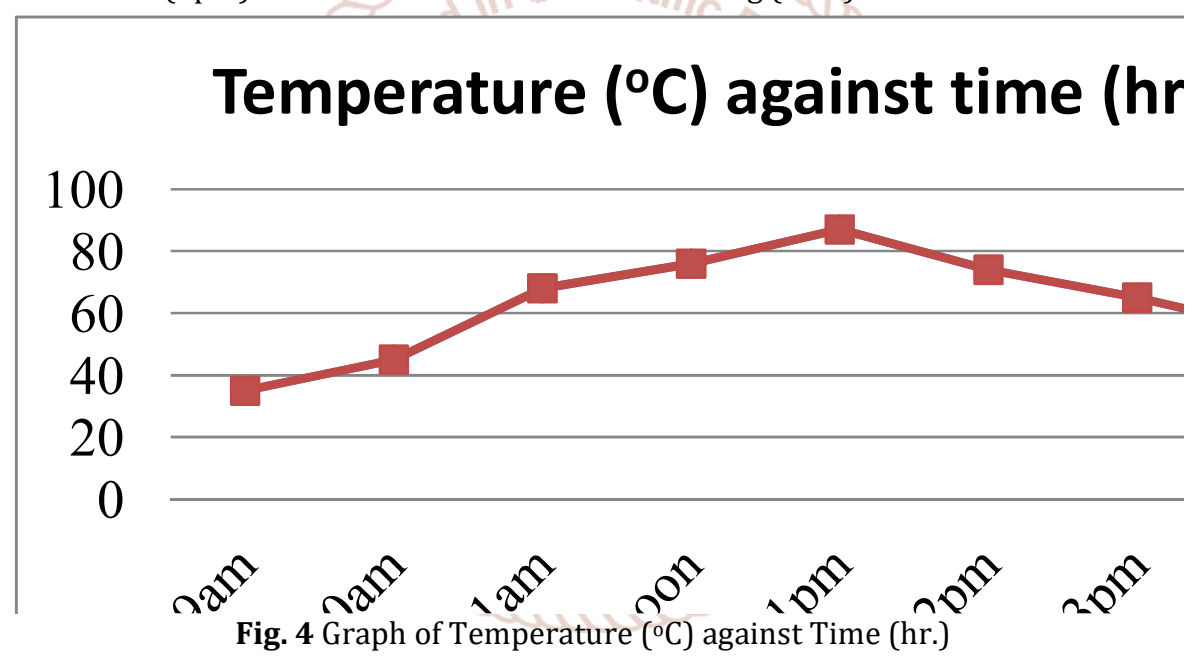

Moreover, enough heat was obtained from morning (9am) to evening (4pm) as a result of temperature variation from $30^{\circ} \mathrm{C}$ to $80^{\circ} \mathrm{C}$. This is an indication that the fish can be dried properly. The temperature analysis using SolidWork is shown in Figure 5 . The analysis pointed out the area of more and less heat concentration. The inner part of the drying chamber tends to absorbed more heat from the radiated sun. The colour changes from blue to green; yellow and finally red is an indication of increase in temperature. Thus, sufficient heat was gotten for the drying purpose. The displacement analysis is shown in Figure 6. The results confirmed failure in most stressed parts of the component. Failure will occur in this part as a result of continuous heat. The deformation is more severe at the red portion of the analyzed component and least at the blue section.
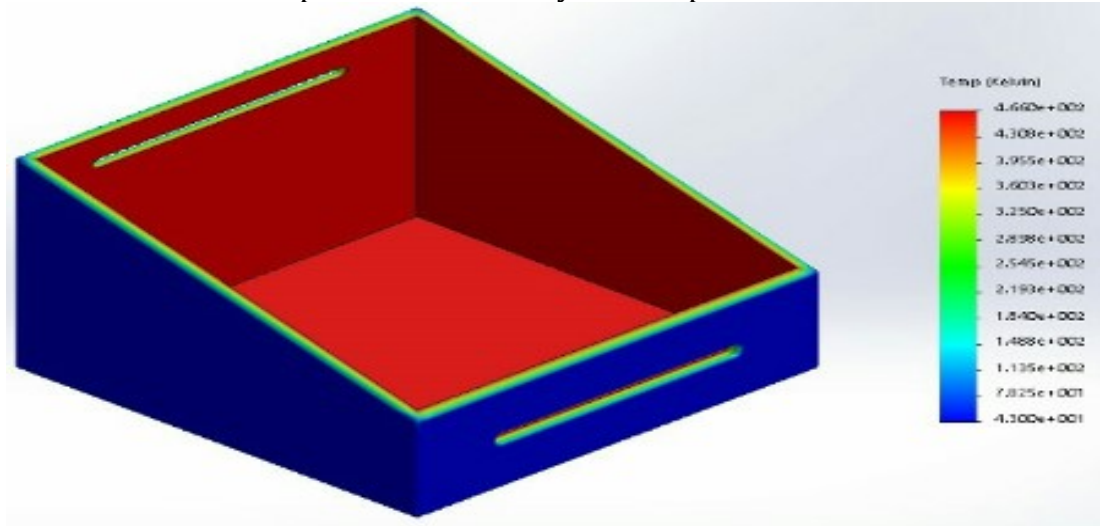

Fig. 5 Temperature Analysis using SolidWork 


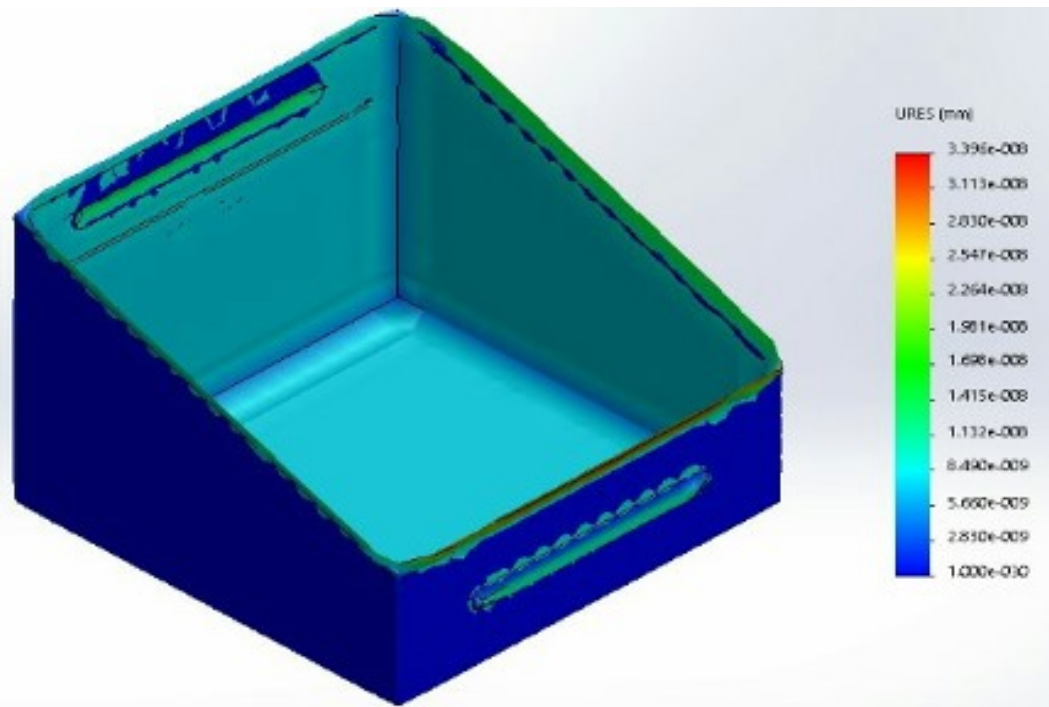

Fig. 6 Displacement Analysis using SolidWork

The stress analysis of the solar dryer is shown in Figure 7. The sun radiation applied heat which in turn imposes stress on it. The portion with red colouration is the most stress area unlike the other sections such as blue, green, and yellow. The less stress area is as a result of lagging material used.

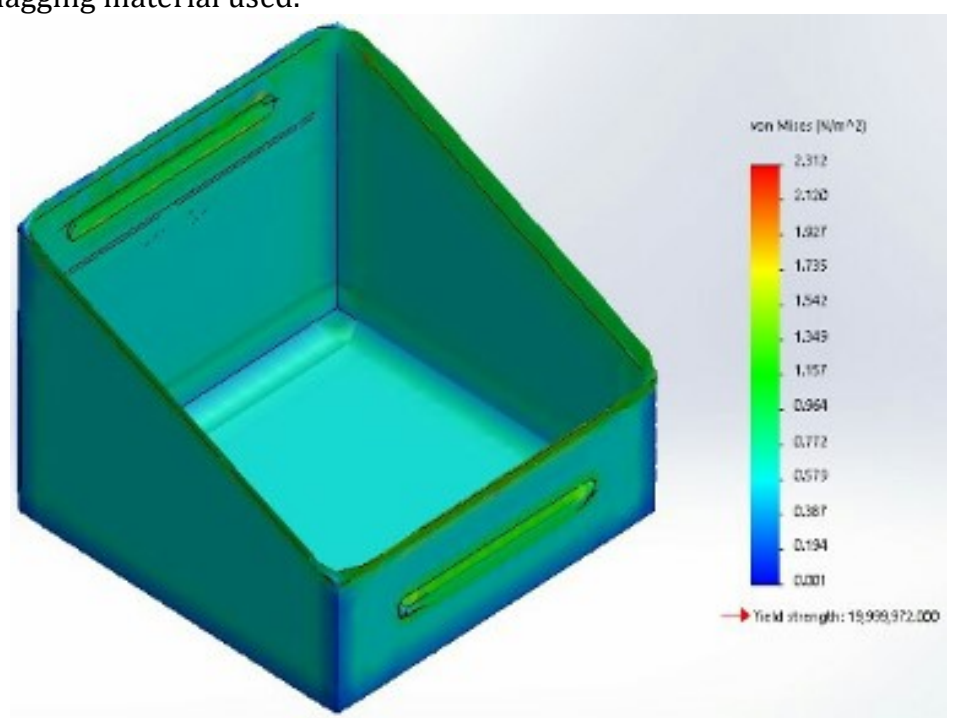

Fig. 7 Displacement Analysis using SolidWork

Figure 8 shows the strain analysis of solar fish dryer. The heat generated resulted to shrinkage of the component. The amount of shrinkage increases simultaneously with blue having the least shrinkage, and red section the most affected part.

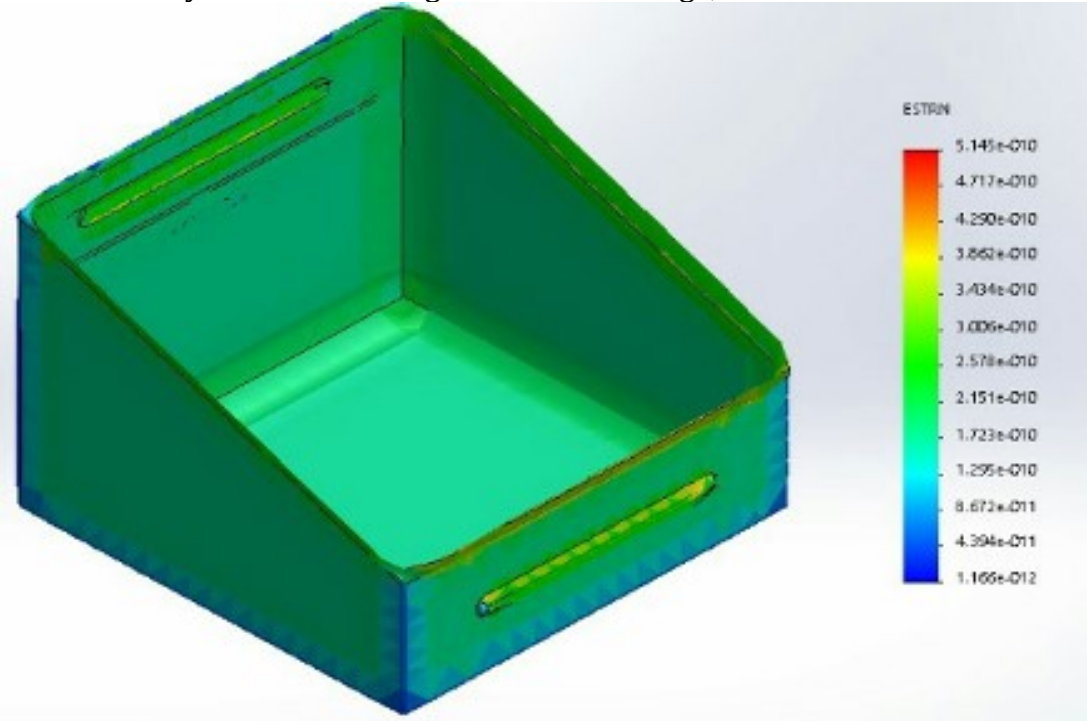

Fig. 9 Displacement Analysis using SolidWork 


\section{Conclusion}

This research work is focused on the design, construction and simulation of solar fish dryer. In this research work the useful heat gain by the solar collector was calculated and obtained as $0.119 \mathrm{kw}$. The temperature of the inner surface of the glass (dryer) was determined as $94.8^{\circ} \mathrm{C}$. The result obtained from the design of the drying chamber shown that an area of $0.12 \mathrm{~m}^{2}$ is required for the system. Moreover, the area of the flat plate collector was obtained as $0.49 \mathrm{~m}^{2}$. The temperature of the sun acting on the outer surface of the plane glass was obtained as $268.4^{\circ} \mathrm{C}$ while the effective heat gain is obtained as $0.115 \mathrm{kw}$. Thus, there is a reduction in the effective heat as a result of heat absorbed by the aluminium and side heat transfer. An optimum drying temperature was achieved between $9.00 \mathrm{am}$ to $2.00 \mathrm{pm}$. Thus, for optimum performance, exposure between $9 \mathrm{am}-2.00 \mathrm{pm}$ is necessary. The outcome of the performance test show that the solar dryer performed perfectly okay. Therefore, the solar fish dryer can replaced the traditional method that is unhygienic and not environmental friendly.

\section{References}

[1] Ahmed, T.M., Agbelege, 0.0., An Appraisal of the Traditional Fish Handling and Processing Methods in Lake Chad, proceding of the Fisheris Society of Nigeri, 22nd Annnual Comference Kebbi 46-51, 2007

[2] Akinneye, J.O., I.A. Amoo and S.T. Arannilewa., Effect of drying methods on the nutritional composition of three species of (Bonga sp., Sardinella sp. and Heterotis niloticus), Journal Fish International, 2(1): 99-103, 2007

[3] Al-Jufaili, M S, Opara, L.U., Status of fisheries postharvest industry in the Sultanate of Oman: Part 1. Handling and marketing system of fresh fish. Journal of fisheries international, (2-4): 44-49b, 2006

[4] Emere, M.C., Dibal, D.M., A Survey of the Methods of Fish Processing and Preservation Employed By Artisanal Fishermen in Kaduna City, Food Science and Quality Management, 11, 16-22, 2013

[5] Udoliza, R. E. K., Akinyemi, A. A., Olaoye, 0. J., Occupational and Health Hazards in Nigeria Coastal Artisanal Fisheries. Journal of Fisheries and Aquatic Science, 8: 14-20, 2013

[6] FAO, The prevention of losses in cured fish. FAO Fish Tech. Paper., (219): 87 p. ILOI Government of Norway
(1984) Zmprousd Village Technology for Women's Activities-Q Manual for West Africa, 2012

[7] Zakia, A.M., Ahmed, M., Dosoki, I., Shaimaa, A.B.O., Nasr, A., Review Article; Occupational Hazards in Fish Industry. World Journal of Fish and Marine Sciences, 4(2), 201- 210, 2012

[8] George, F.O.A., Ogbolu, O.A., Olaoye, O.J., Obasa, O.J., Idowu, A.A., and Odulate, D.O., Fish processing technologies in Nigeria: A Case Study of Ibeju-Lekki Local Government Area, Lagos State, American Journal of Food Technology, 9(6),302-310, 2014

[9] Adeyeye, S.A.O., Traditional fish processing in Nigeria: a critical review, Nutrition \& Food Science, 46, (3)321, 335,2016

[10] Olaoye, O. J., Odebiyi, O. C., Abimbola, O. T., Occupational Hazards and Injuries Associated with Fish Processing in Nigeria, Journal of Aquatic Science, 3, (1) 1-5, 2015

[11] Tawari, C.C., Abowei, J.F.N., Traditional Fish Handling and Preservation in Nigeria, Asian Journal of Agricultural Sciences 3(6): 427-436, 2011

[12] Akinola, O.A., Akinyemi, A.A., Bolaji, B.O., Evaluation of Traditional and Solar Fish Drying Systems towards Enhancing Fish Storage and Preservation in Nigeria, Journal of Fisheries International, 1(2-4), 44-49, 2006

[13] Orhorhoro, E.K., Orhorhoro, W.O., Atumah, V., A study of energy audit of solar panel (PV) manufacturing plant in Nigeria, Asia Pacific Journal of Mechanical Engineering Research, 2(2), 2016

[14] Onyebuchi, E.I., Alternative Energy Strategies for the Developing World's Domestic Use: A Case Study of Nigeria Household's Final Use Patterns and Preferences, Energy Journal, 10(3), 121 - 138, 1989

[15] Orhorhoro, E.K., Orhorhoro, W.O., Ikpe, A.E., A Study of Solar Energy Potential in Sapele, Nigeria, Int. J. of Thermal \& Environmental Engineering, 13 (2), 129133,2016

[16] Izah, L.A., Study, Design, and Analysis of a Solar Power System Suitable for use in Nigeria, Unpublished PhD thesis.

[17] Rajput, R.K., Heat and mass transfer, Revised Edition, 2008, ISBN: 81-219-2617-3 